\title{
Assessing Indonesian Local Government eGovernment- eService Quality: Dimensions and Alternative Model of eService Quality from Banyuwangi's SIPO (Online Permit Registration System)
}

\author{
Rachmat Hidayat ${ }^{1)}$, Tree Setiawan Pamungkas ${ }^{2)}$ \\ 1. Lecturer of Postgraduate Administrative Study Dept, University of Jember, J1 Kalimantan Kampus \\ Bumi Tegalboto, Jember 68121, Indonesia \\ 2. Lecturer of Public Administration Dept, University of Jember, J1 Kalimantan Kampus Bumi \\ Tegalboto, Jember 68121, Indonesia \\ *E-mail of the corresponding author: rachmat.hidayat@unej.ac.id
}

\begin{abstract}
A decentralized mode of local government in Indonesia has subsequently leads to a local initiative for the improvement of local government public service delivery. The regency of Banyuwangi launch an eService Online Permit Registration System (SIPO), which covers 45 type of mostly local business licenses. This paper sought to asses local government eService Quality in the context of one local government in Indonesia, especially in the regency of Banyuwangi in the eastern part of Java. The quantitative approach is used in this research, as well as the application of Structural Equation Modelling for integrating the analysis among three important dimensions of eService: Organization, Information and the service quality. The study finding proposes an alternative model for assessing eService at local government which highlight the important of content management, the stable of eService operating system, and the organizational efficiency as the backbone of eService based at local government level.
\end{abstract}

Keywords: eService model, Decentralization, East Java

DOI: $10.7176 / \mathrm{PPAR} / 9-1-04$

\section{Background of the Study}

Information technology not only offers low costs to obtain information and reservations that can be made online, but also provides a means of communication among tourism suppliers, intermediaries, and endconsumers (Kim, 2004). With the current developments and a decentralized mode of government, almost all organizations adopt information technology, not only to reduce costs and efficiency, but also as a means to provide services to ensure customers' satisfaction. To provide maximum benefit from adopting technology by companies and governments and provide satisfying services, and open business opportunities, providing adequate information and communication technology infrastructure is requirement that must be met by the company.

Limi (2008) states that infrastructure is one of the most important supporting factors in economic development. Platforms embedded in information technology, such as personal computers, mobiles, internet, databases and others, have major contributions in organization. According to Piatkowski (2003), there are three contributions provided by information technology platforms that pose an impact on organizational performance, namely (1) providing business feasibility, (2) providing more accurate, reliable, up to date information to the company, and (3) providing solutions to classic problems faced by companies in business activities. The use of e-mail, social network media makes one easily follow the development of the information needed.

Indonesian political devolution of decentralization has shifted the role of innovation for Indonesian local government at local level (Hidayat,2017). Further, Information technology development in the field of services carried out by Banyuwangi Regency has been carried out in various fields. One of the developments of information technology-based services is the Online Permit Registration System (SIPO). SIPO is a system developed by the Agency of One Door Investment Services and Integrated Services of Banyuwangi Regency. SIPO can be used for the registration process of 45 licensing services in Banyuwangi Regency.

A previous research (Parasuraman et al., 2000) shows that the implementation of online public services is influenced by the quality of the system and also the quality of information including 10 (ten) dimensions of quality (reliability, responsiveness, competence, access, courtesy, communication, credibility, security, understanding and tangible). Several other studies have also found that an online public service is influenced by service quality and information quality (Aladwani, 2002; Cai, 2003; Barnes, 2002; Jun 2004; Li, 2002; Loiacono, 
2002; Parasuraman, 2005; Sohn, 2008; Yang, 2004).

\section{Dimensions of Service, Information, and Organization Quality of eService}

Service quality is generally related to the quality of service content and service delivery (Tan, Benbasad and Cafetely, 2013). Furthermore, Hien (2014) points out that the quality of services is related to the measurement of how well the services provided are able to meet users' needs and desires. In the development of further services, Parasuraman et al. (2000) state that the quality of online services is to extent to which a web site facilitates efficient and effective shopping, purchasing, and delivery.

In terms of the development of online public services, the emergence of self-service technology (SST) has come under the spotlight. SST refers to interface technology that allows service users to independently carry out services, rather than involving service personnel (Meuter, 2000). SST offers several advantages, comprising of reduced service costs, easy access to information, alternative support methods, and better service. Given the importance of self-service technology (SST), there are 3 (three) key dimensions need investigation with respect to Quality Service perspective.

- Reliability: service providers are able to provide accurate and reliable services

- Communication: care for customers and ease of access to services can be informed to service users through various channels

- Responsiveness: agency is willing to help service users get services quickly and efficiently.

In relation to the variable quality of e-Government information services, there are 2 (two) key words, namely conveying information to the public and increasing government transparency (Ma et al., 2005). The aim of the egovernment system is to provide useful and vital information, which is also credible and accessible, in timely manner (Baker, 2009). User assessment of information provided by the government is concerned with how useful information provided by the government is (Wu, Liu, Wang and Wang, 2013). In this study, ease of use, content, level of security, and trust in information become key dimensions. Organizational variables are deemed essential in a system. In the context of public services, organizations are related to organizational management and support. They are also related to the internal process of an organization to provide services to users (Hien, 201). In this study there are 2 (two) main dimensions namely system efficiency and system stability in the process of public service. The following figure is the modeling applied in this study. This research model places 8 (eight) dimensions and 3 (three) main variables, which involve quality service, information service perspective, organization service perspective on eService in Banyuwangi regency.

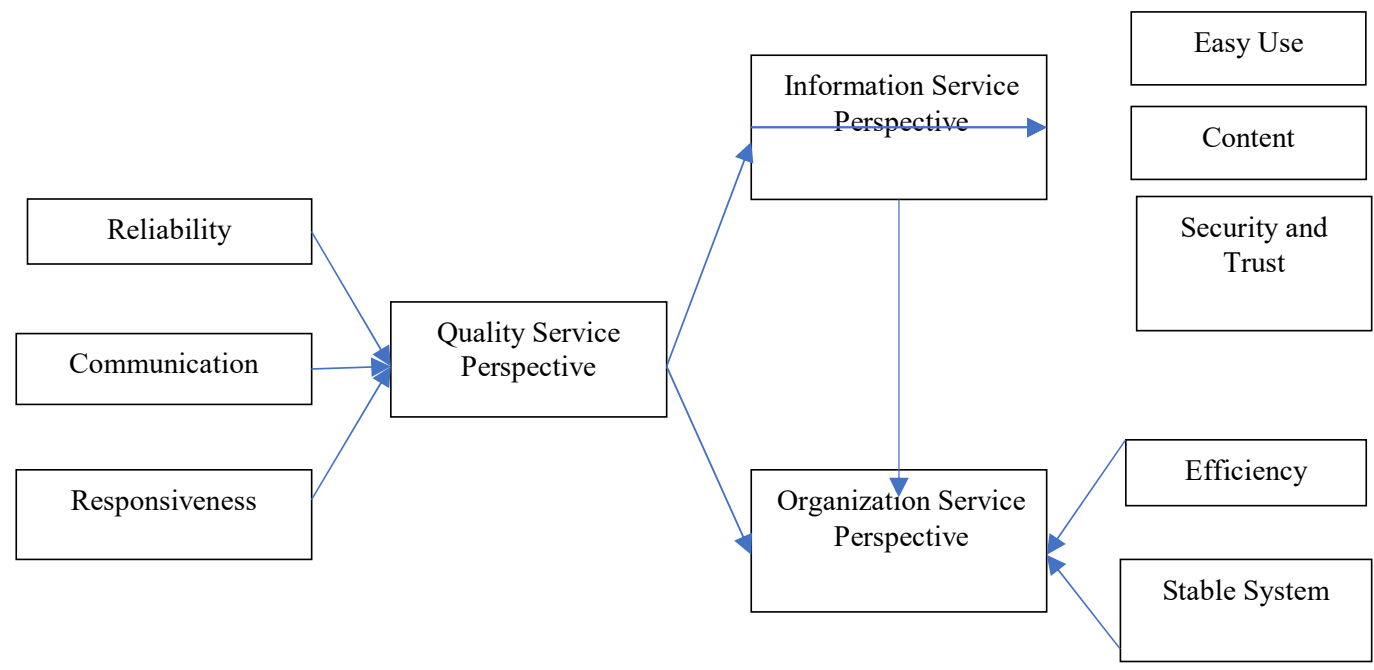

Figure 1. Research Model of eService SIPO in Banyuwangi Regency 


\section{Analysis of the Model}

This study aims to identify quality service perspective, information service perspective, and organization service perspective on the implementation of online licensing services (SIPO) in Banyuwangi regency. To identify some of these variables, quantitative approach is at work. Variables of identification are investigated questionnaires distributed to users of online services in Banyuwangi regency. The Likert scale is used in each question, where a scale of 1 indicates very strong disagreement, while a scale of 5 indicates very strong agreement. To test the hypothesis, CFA (Confirmatory Factor Analysis) technique is used, which is coupled with path analysis, a part of SEM (Structural Equation Modeling). Data analysis deploys Lisrel and SmartPLS software.

\section{The SIPO eService user in Banyuwangi}

This study involved the people of Banyuwangi as research respondents. The respondents were users of the Online Permit Registration System (SIPO) developed by the One-Door Investment Services and Integrated Services of Banyuwangi Regency. Data collection was carried out for 2 (two) months from August to September 2018. Respondents could be categorized into several groups based on age, gender, education, employment and income. Based on the age group of respondents, the respondents were categorized into 5 (five) intervals namely age $<20$ years, age 20-29 years, age 30-39 years, age 40-49 years and also age $>50$ years. Specifically, the age category of respondents is presented in the following table.

Table 1. Respondent Category based on Age Group

\begin{tabular}{|l|r|r|}
\hline \multicolumn{1}{|c|}{ Category } & Frequency & \multicolumn{1}{|c|}{ Percent } \\
\hline$<20$ years & 2 & 2,777778 \\
\hline 20 - 29 years & 24 & 33,33333 \\
\hline $30-39$ years & 19 & 26,38889 \\
\hline $40-49$ years & 18 & 25 \\
\hline$>50$ years & 9 & 12,5 \\
\hline Total & 72 & 100 \\
\hline
\end{tabular}

Most of the respondents in this study are at the age of 20-29 years with a total of 24 people. In the age group of 30-39 years, 19 people are involved. In the third place is the age group 40-49 years with a total of 18 people. The fourth age group $>50$ years involves a total of 9 people. The highest group, aged $<20$ years with a total of 2 people. The results clearly indicate that most applicants are in productive age. Furthermore, based on gender category, respondents are categorized into 2 (two) genders or gender groups, namely men and women. The results of the study showed that some respondents were men with a total of $55.56 \%$. Distribution of respondents based on gender categories is presented in the following table:

Table 2. Respondent Category based on Gender

\begin{tabular}{|c|c|c|}
\hline Gender & Frequency & Percentage \\
\hline Male & 40 & 55,55556 \\
\hline Female & 32 & 44,44444 \\
\hline Total & 72 & 100 \\
\hline
\end{tabular}

Based on the education level, the respondents are categorized into primary education, secondary education, and tertiary education. Judging from the education level group, the majority of respondents are college graduates, which reaches $47.22 \%$ of the entire group. This is followed by secondary education with a total of $44.44 \%$. In the third position, respondents with primary education reach $8.33 \%$ of the total population. As such, it can be seen that the majority of respondents have secondary education and tertiary education. Grouping of respondents' level of education can be seen in the following table: 
Table 3. Respondent Category based on Education Level

\begin{tabular}{|l|r|r|}
\hline \multicolumn{1}{|c|}{ Education Level } & Frequency & Percentage \\
\hline Primary Education & 6 & 8,333333 \\
\hline Secondary Education & 32 & 44,44444 \\
\hline Tertiary Education & 34 & 47,22222 \\
\hline Total & 72 & 100 \\
\hline
\end{tabular}

Based on professions, the respondents can be categorized into 7 (seven) groups, namely civil servants, entrepreneurs, traders, private employees, farmers, employees at informal, and other Sectors. The research results evince that the majority of respondents are in 4 (four) professions, namely private employees with a total of $29.17 \%$, entrepreneurs with a total of $22.22 \%$, traders with a total of $18.06 \%$, and other jobs with a total of $15.27 \%$. By contrast, those working as civil servant contribute only $8.33 \%$. Informal sector workers comprise of $4.17 \%$ of total population. The group working as farmers accounts for $2.78 \%$ of total respondents. Respondents based on their professions are categorized in the following table.

Table 4. Respondent Category based on Based on Profession

\begin{tabular}{|l|c|c|}
\hline \multicolumn{1}{|c|}{ Professions } & Frequency & Percentage \\
\hline Civil servants & 6 & 8,333333 \\
\hline Entrepreneurs & 16 & 22,22222 \\
\hline Traders & 13 & 18,05556 \\
\hline Private employees & 21 & 29,16667 \\
\hline Farmers & 2 & 2,777778 \\
\hline Employees at informal sector & 3 & 4,166667 \\
\hline Others & 11 & 15,27778 \\
\hline Total & 72 & 100 \\
\hline
\end{tabular}

Based on income, the respondents can be grouped into several income levels, ranging from Rp 500.000$\mathrm{Rp}$ 1.000.000, Rp 1.000.000-Rp 1.500.000, Rp 1.500.000-Rp 2.000.000, and over Rp 2.000.000. From the research results, most respondents with income $>2$ million account for $47.2 \%$ of total sample. Those with income ranging from 1.5 million - 2 million include $31.94 \%$ of total sample. Respondents with income ranging from 1 million to 1.5 million reach $18.06 \%$ of total sample. In addition, those with income of 500 million- 1 million contribute $2.78 \%$ to the overall sample. The table of the characteristics of respondents based on the amount of income as follows.

Table 5. Respondent Category based on based on Income

\begin{tabular}{|l|c|c|}
\hline \multicolumn{1}{|c|}{ Income Category } & Frequency & Percentage \\
\hline Rp 500.000-Rp 1.000.000 & 2 & 2,777778 \\
\hline Rp 1.000.000-Rp 1.500.000 & 13 & 18,05556 \\
\hline Rp 1.500.000-Rp 2.000.000 & 23 & 31,94444 \\
\hline Over Rp 2.000.000 & 34 & 47,22222 \\
\hline Total & 72 & 100 \\
\hline
\end{tabular}

\section{Analysis and Results}

The analysis is divided into three parts. In the first and second parts, Lisrel statistical software is operative for the analysis. The first part measures the relationship between variables in the study. With the aim of knowing whether relationship exists between variables and how strong the relationship is between variables in eService. 
The second part measure the effects of each variable in eService. This is done to find out whether the relationship has a significant influence or not. In addition, it delves into whether the influence is negative or positive on eService. In the third part, modeling is conducted using Structural Equation Model (SEM).

\subsection{The Correlation among eService Dimensions and Variables}

Relationship investigation is done by connecting each dimension through a predetermined latent variable. A latent variable consists of quality service perspective, information service perspective and organization service perspective. Before testing the relationship between latent variables, the analysis investigates the relationship of each dimension is with each latent variable.

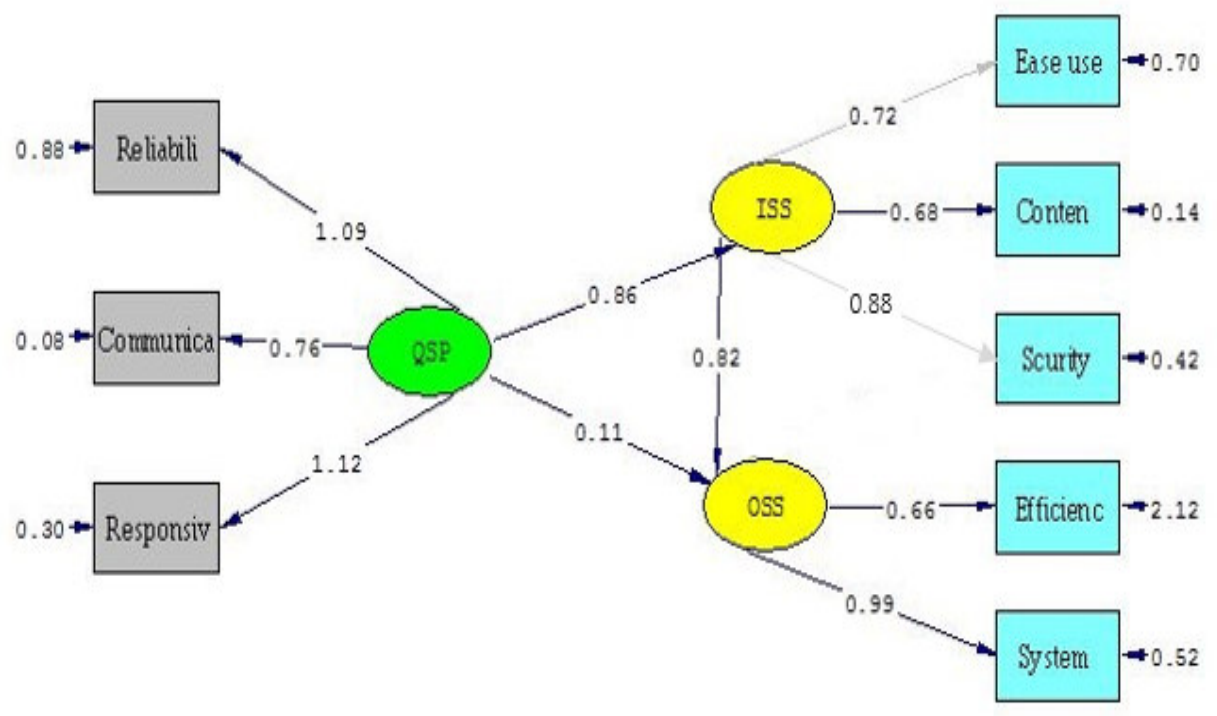

Chi-Square $=46.10, d f=17, P-$ value $=0.00017$, RMSEA $=0.155$

Figure 2. The Analysis Results on Correlation Test

The test results of the relationship among the dimensions with each latent variable indicate the following findings:

1. The relationship between reliability and other dimensions through latent quality service perspective variables indicates strong relationship.

2. The relationship between communication and other dimensions in the quality service perspective variable shows strong relationship.

3. The relationship between responsiveness and other dimensions in the quality service perspective variable shows a strong relationship.

4. The relationship between ease of use and other dimensions in information service perspective indicates weak relationship.

5. The relationship between content and other dimensions in information service perspective variables shows strong relationship.

6. The relationship between security and other dimensions in the organization service perspective variable indicates weak relationship.

7. The relationship between the efficiency dimension and other dimensions in the Organization service perspective variable shows a strong relationship.

8. The relationship of the system dimension with other dimensions in the organization service perspective variable shows strong relationship.

After testing the relationship of each dimension through latent variables, the relationship between each latent 
variable is tested. The test results are presented as follows.

1. The Relationship between Quality Service Perspective and Information Service Perspective

Based on the test results on the relationship between the Quality Service Perspective and the Information Service Perspective, strong relationship is evident between the two. This is indicated by the t-test value of 0.86 , which shows a strong relationship between quality service perspective and information service perspective.

2. The Relationship between Quality Service Perspective and Organization Service Perspective

The test results on the relationship between service quality perspective and organization service perspective reveal relationship between the two. However, the relationship between quality service perspective on organizational perspective is not significant, as this is indicated by the t-test value of 0.11 .

3. The Relationship between Information Service Relations Perspective and Service Perspective Organization

The test results on the relationship between information service perspective and organization service perspective indicate that there is a relationship. The t-test value of the information service perspective relationship with the organization service perspective is 0.82 . This shows that there is a significant relationship between informational service perspective and organization service perspective.

Based on the test results on the relationship among all dimensions and variables, not all dimensions pose strong influence on each variable and dimension. Ease of use and security dimensions do not have a strong relationship with other dimensions and variables. By contrast, the latent quality service perspective variable does not have a strong relationship with the organization service perspective.

\subsection{The Effect among eService dimensions and variables}

The correlation analysis conducted to see the influence of each variable. Relationship testing is done using Lisrel. The dimensions of each latent variable are tested for influence on each dimension through latent variables. The results of the relationship test between variables can be seen in the following figure:

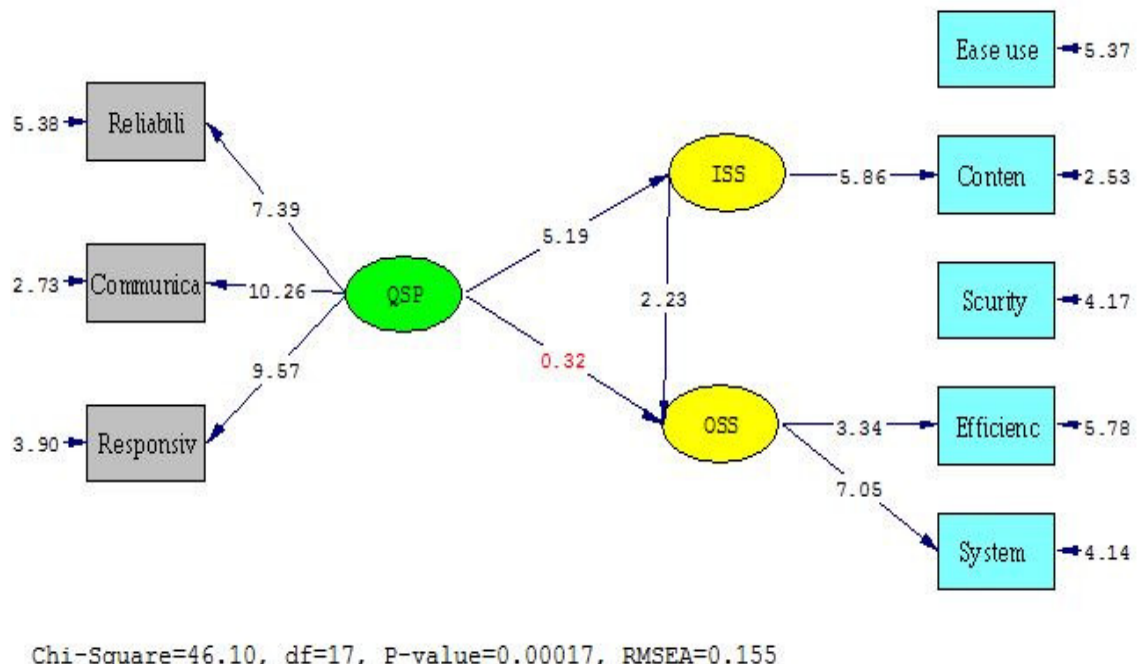

Figure 3. The Analysis Results on Correlation Test

Based on the results of the test of the relationship between dimensions through each latent variable, the researchers revealed the following findings. 
1. There is positive influence of reliability dimensions on other dimensions through latent quality service perspective variable. This influence is proven significant.

2. There is positive influence of communication dimension on other dimensions in quality service perspective variable. This influence is proven significant.

3. There is a positive influence on the dimensions of responsiveness with other dimensions in the variable quality service perspective. This influence is significant

1. There is no effect of the easy of use on other dimensions in Information service perspective variable.

2. There is a positive influence on the Content dimension with other dimensions in the Information service perspective variable. This influence is proven significant.

3. There is no influence of security on other dimensions in the Information service perspective variable.

4. There is positive influence of the efficiency on other dimensions in the Organization service perspective variable. This influence is proven significant.

5. There is positive influence of system on other dimensions in the Organization service perspective variable. This influence is proven significant.

To investigate the effect between each latent variable, the relationship between latent variables is put under analysis with the following results.

1. There is significant influence between quality service perspective variables and information service perspective as evinced by t-test value of 5.19 .

2. There is significant influence between information service perspective and organization service perspective variables as eivnced by t-test value of 2.23 .

3. There is significant influence between quality service and organizational service, as evinced by a t-test value of 0.32 . However, the influence of these two variables is not significant.

Based on the analysis results of all dimensions and variables in this study, there are several things the authors can draw. First, the dimensions of ease of use and security have no influence on other dimensions and variables. Second, quality service perspective does not have significant effect on the variable of organization service perspective. Thus, there are only two significant effects, that is the quality service perspective on the information system perspective and the information system perspective on the variable organization service perspective

\section{3. eService dimensions and variables Analyzing and Structural Equation Modeling}

In this section, a modeling analysis is performed using structural equation modeling using SMARTPLS. The results of the analysis using Structural Equation Modeling can be seen in the following figure.

The analysis results have found out the coefficient value of each dimension to other dimensions. Hereunder are some dimensions which have a high coefficient value.

1. The dimension of communication to reliability with a coefficient value of 0.557

2. The dimension of system reliability dimensions to stable system dimensions with coefficient value of 0.503

3. The dimension of stable system dimensions to efficiency dimension with a coefficient value of 0.506

4. The dimension of ease of use toward security and trust emission with coefficient value of 0.410 .

The analysis performed in the study has identified several relationship patterns and important dimensions as well as variables in the public service of online licensing in Banyuwangi regency, which encompasses the following.

1. Quality Service has a strong relationship and poses a significant influence on information servicer perspective. Thus, the quality service in online service conditions in Banyuwangi regency is deemed important in the provision of information service

2. Information service has strong relationship and poses significant influence on organizational service perspective. Therefore, information service toward online service conditions in Banyuwangi regency is considered important to provide an organization service.

3. Quality service perspective has weak relationship and does not have significant relationship with organization service. As such, quality service in online service conditions in Banyuwangi regency is considered inessential in providing organization service.

4. The dimension of ease of use and security as well as trust have weak relationship and no significant influence on all indicators and variables. As a corollary, in the online service conditions of Banywuangi ristrict, these dimensions do not have vital role in providing quality online services.

5. Dimensions of reliability, communication, responsiveness, content, efficiency and stable system in the online service conditions in Banyuwangi regency make very substantial contribution to the creation of 
online services in Banyuwangi regency. This is based on the test results related to the relationship and influence among dimensions, which indicates a strong relationship and significant influence.

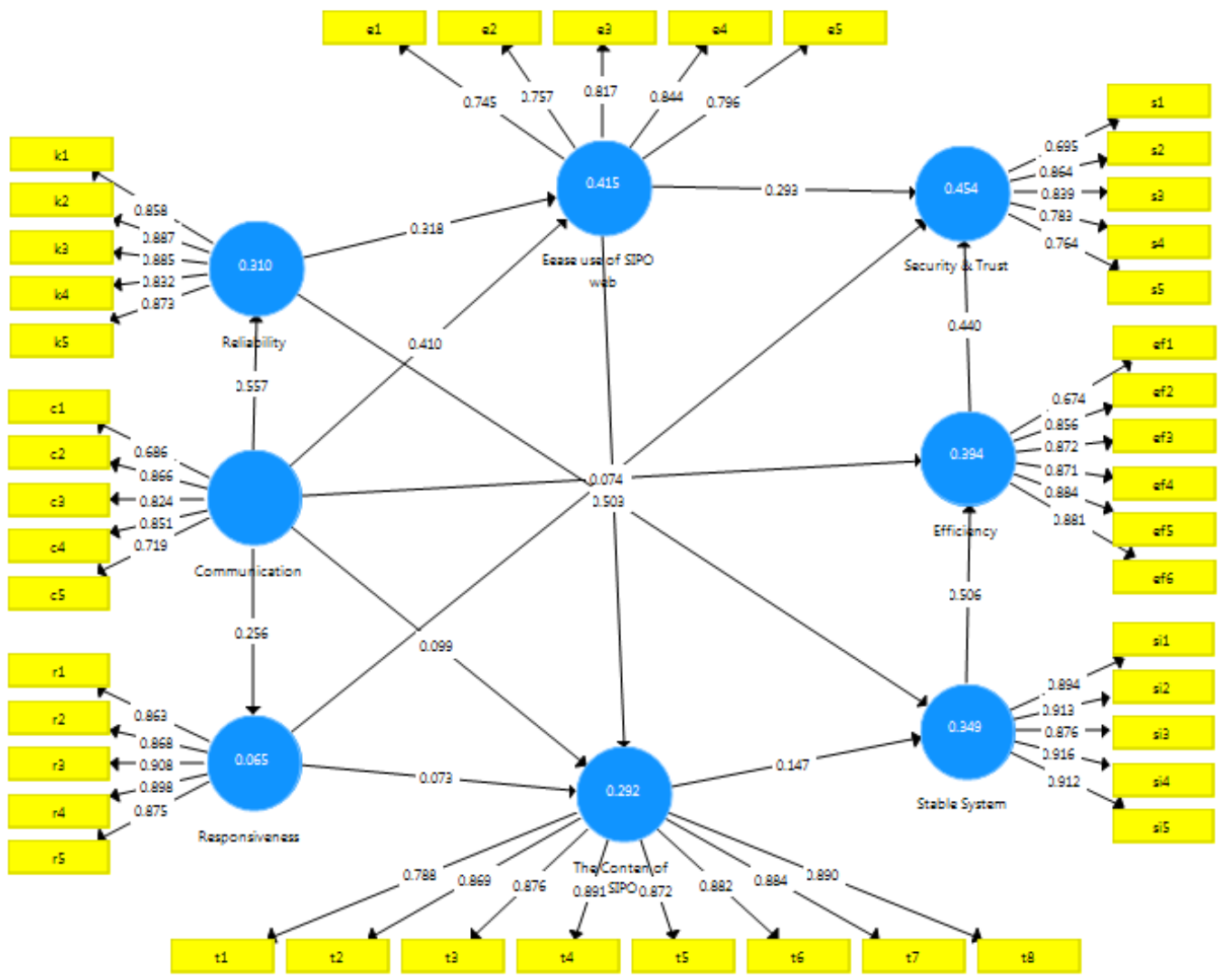

Figure 4. Modeling the eService Dimensions from Banyuwangi

\section{Conclusion and Implication: Alternative Model for assesing eService at local government level}

Subsequent to analyzing various variables in eService research of Banyuwangi regency, there are some interesting findings which worth careful discussion in this study are. This study has found that not all variables and dimensions hold strong relationship and pose significant influence on other dimensions and variables. From the results of the relationship analysis, quality service is proven to have weak relationship with organization service. This is corroborated by test results germane to the effect of quality service on the organization service perspective, which does not demonstrate significant relationship.

The relationship and the influence of quality service perspective on an organization service perspective can be interpreted in the results of research conducted on online services in Banyuwangi regency. The quality service perspective is considered inessential in actuating the organization service perspective framework. Therefore, the organizational process does not necessarily take into account the quality of service received by service users.

In addition to the relationships and influences between variables, the analysis on relationships and the influence of the dimensions in this study highlights some interesting results. The dimensions of ease of use and security and trust have weak relationship with other dimensions and variables, and nor do they pose influence on other dimensions and variables. Thus, these two dimensions are considered insignificant in the online service process of Banyuwangi regency.

The implementation of online services in Banyuwangi regency needs to ponder several things for service improvement. First, in the quality service perspective variable, each dimension needs to be given emphasis because the research results indicate that reliability, communication, and responsiveness as a whole have strong 
relationship and significant influence on the overall online service process in Banyuwangi regency.

Second, the information service perspective variable is only the dimension of the content that is considered to have a strong relationship and a significant influence on the overall service process. By contrast, the dimensions of easy use and security and trust do not have strong relationship and do not have influence on the overall online service process. Third, in the organization service perspective variable, the efficiency and system dimensions must be improved to improve the overall online service process.

From the modeling created based on eService in Banyuwangi regency, this research has identified several important dimensions and variables within the eGov platform. The following figure summarizes these variables and dimensions into a model that integrates eService-based eGov quality that is established by combining the dimensions of organizational quality and information quality in the eService mechanisms. On the service user side, this model identifies the importance of online service system reliability factors, effective communication and steady responsiveness from eService service personnels to be strategic in the eService-based eGov services.

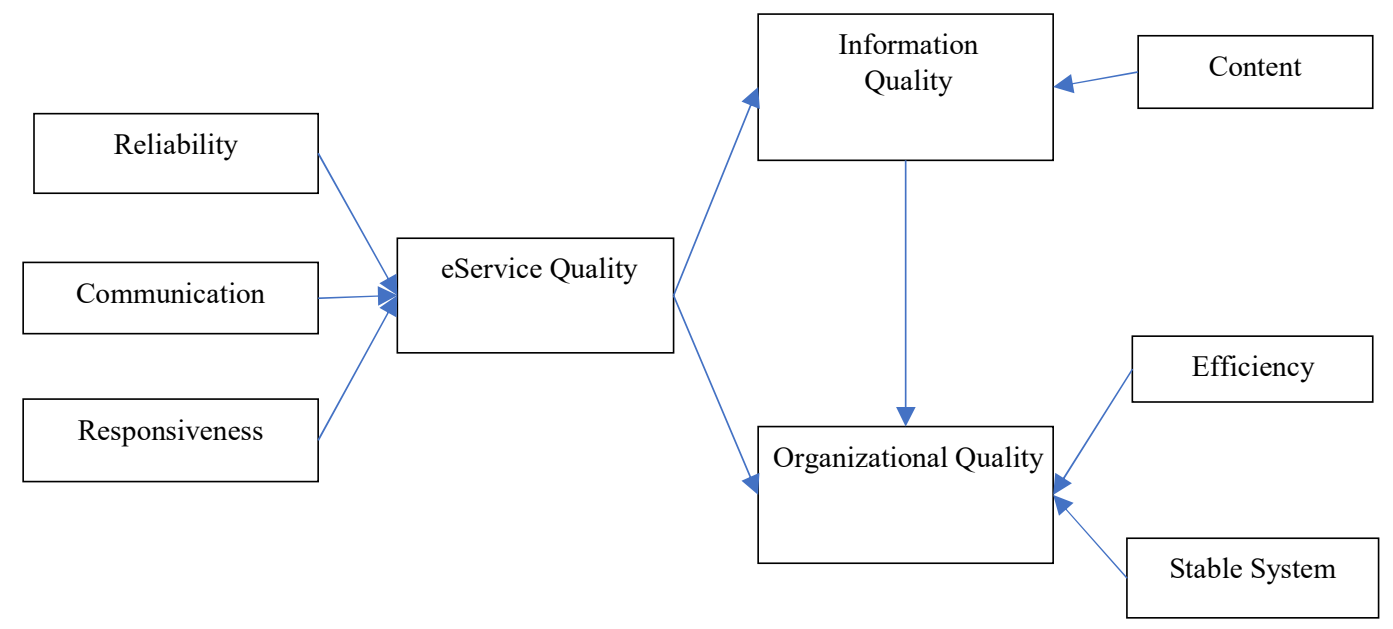

Figure 5. The Dimension for assesing eService at local government level

\section{Recommendation}

The research results on online licensing services in Banyuwangi regency have shed lights on the interaction, influence, and relationship of the dimensions pertinent to the quality of eService. This study also proposes an alternative model of eSevice assessment at the local government level that will run effectively by paying attention to several aspects for improvement, grounded within the experience of local governments in Indonesia, specifically Banyuwangi regency. Hereunder are important implications concerning strategic points garnered which are worth emphasis from the study.

1. Increasing the awareness of service providers about service users and providing accurate services

2. Improving communication media, clarity of content, and service information to ensure easy access for service users

3. Accruing the willingness and care of service personnel to provide assistance to service users in order to facilitate and accelerate services

\section{References}

Aladwani, A.M., Palvia, P.C., (2002) Developing and validating an instrument for measuring user-perceived web quality. Information and Management, 467-476.

Baker, D.L. (2009). Advancing e-Government performance in the United States through enhanced usability benchmarks. Government Information Quarterly, 26(1), 82-88.

Barnes, S.J., Vidgen, R.T., (2002) An integrative approach to the assessment of E-commerce quality. Journal of Electronic Commerce Research 114-127. 
Cai, S., Jun, M., (2003) Internet users' perceptions of online service quality: A comparison of online buyers and information searchers. Managing Service Quality 504-519.

Hidayat, R. (2017). Political Devolution: Lessons From a Decentralized Mode of Government in Indonesia. SAGE Open, 7(1), 2158244016686812.

Hiyen, Nguyen Manh, (2014) A Study on Evaluation of E-Government Service Quality, Journal of Humanities and Social Science, 16 - 19

Jun, M., Yang, Z., Kim, D.,. (2004) Customers' perceptions of online retailing service quality and their satisfaction. International Journal of Quality and Reliability Management, 817-840.

Li, Y.N., Tan, K.C., Xie, M., (2002) Measuring web-based service quality. Total Quality Management and Business Excellence 685-700.

Limi, H., \& Suomi, R. (2008). A Proposed Scale for Measuring E-service Quality. International Journal of eService, 1-10.

Loiacono, E.T., Watson, R.T., Hoodhue, (2002) D.L. WEBQUAL: measure of web site quality. Marketing Educators Conference: Marketing Theory and Applications 432-437.

Kim, DO Yeong, The Implicit Life Satisfaction Measure, Asian Journal of Social Psicology, 2004, $236-262$.

Ma, L., Chung, J., \& Thorson, S. (2005). E-government in China: Bringing economic development through administrative reform. Government Information Quarterly, 22(1), 20-37.

Meuter, M.L., Ostrom, A.L., Roundtree, R.I., and Bitner, M. J., (2000) "Self-Service Technologies: Understanding Customer Satisfaction with Technology-Based Service Encounters," Journal of Marketing, Vol.64, pp. 50-64.

Parasuraman, A., Grewal, D., (2000) The impact of technology on the quality-value-loyalty chain: a research agenda. Journal of the Academy of Marketing Science168-174.

Parasuraman, A., Zeithaml, V.A., Malhotra, A., (2005) E-S-Qual: A multiple-item scale for assessing electronic service quality. Journal of Service Research 213-233.

Piatkowski, M. (2003). Can Information and Communication Technologies Make A Difference in the Development of Transition Economics? Information Tecnologies and International Development, 39-53.

Sohn, C., Tadisina, S.K., (2008) Development of e-service quality measure for internet-based financial institutions. Total Quality Management and Business Excellence 903-918.

Yang, Z., Fang, X., (2004) Online service quality dimensions and their relationships with satisfaction: A content analysis of customer reviews of securities brokerage services. International Journal of Service Industry Management 302-326.

Wu, J., Liu, L., Wang, N., \& Wang, Z. (2013). Interorganizational IT capability in China: exploring the differences between state-owned and non-state-owned enterprises. Journal of System and Management Sciences, 3(3), 14-25. 